\title{
Is Androcentric Archaeology Really About Men?
}

\author{
Lisbeth Skogstrand, Museum of Cultural History, University of Oslo, \\ St.Olavs Plass, P.B. 6762, 0130, Oslo, Norway \\ E-mail: lisbeth.skogstrand@khm.uio.no
}

\begin{abstract}
The article starts with a discussion of the relation between feminist archaeology and gender archaeology followed by a short account of how androcentrism may influence on archaeological research. By exploring two representative examples I will argue that androcentric archaeology mainly reproduces stereotype images of men and do not provide much new or real knowledge about prehistoric men or understandings of masculinity. Consequently, there is a need to study prehistoric men as gendered and I will argue that to include studies in men and masculinity into a gender archaeology based on feminist theory might challenge androcentric archaeological studies just as much as to study women in prehistory.
\end{abstract}

Résumé: Cet article débute par une analyse de la relation entre l'archéologie féministe et l'archéologie de genre, suivie d'un court exposé portant sur la manière dont l'androcentrisme peut influencer la recherche archéologique. Par l'exploration de deux exemples représentatifs, je démontrerai que l'archéologie androcentrique reproduit principalement les images stéréotypées des hommes et n'apportent que peu de connaissances nouvelles ou réelles concernant les hommes préhistoriques ou la compréhension de la masculinité. Par conséquent, il est nécessaire d'étudier les hommes préhistoriques en tant qu'êtres sexués, et je démontrerai qu'inclure les études portant sur les hommes et la masculinité dans une archéologie de genre basée sur la théorie féministe est tout autant susceptible de remettre en question les études archéologiques androcentriques qu'étudier les femmes dans la préhistoire.

Resumen: Este artículo comienza con un debate sobre la relación entre la arqueología feminista y la arqueología de género, seguido de una breve

This article is based on parts of a $\mathrm{PhD}$-thesis in progress with the working title "Warriors and other Men. Notions of Masculinity from the Bronze Age to the Iron Age expressed through burials, 1100 BC-400 AD” (Skogstrand in prep.). 
narración de cómo el androcentrismo puede influir en las investigaciones arqueológicas. Analizando dos ejemplos representativos, arguyo que la arqueología androcéntrica reproduce básicamente estereotipos sobre los hombres y no ofrece mucho conocimiento nuevo o real sobre los hombres prehistóricos ni sobre la comprensión de la masculinidad. Por tanto, es necesario estudiar a los hombres prehistóricos desde la base del género, y postulo que la inclusión de los estudios sobre los hombres y la masculinidad en una arqueología de género basada en la teoría feminista podría hacer peligrar los estudios arqueológicos androcéntricos, de la misma forma que lo haría el estudiar a las mujeres en la prehistoria.

\section{KEY WORDS}

Androcentrism, Feminist theory, Masculinity, Prehistory

Feminist critique has pointed to and criticized androcentrism within archaeology for more than 30 years. It has called attention to the assumption that men occupied all active positions in social and ritual life as well as in the development of society. Women have for the most part been invisible in the interpretations and presentations of prehistory, and when present it is usually as stereotype images according to 19th century ideals (e.g. Bertelsen et al. 1987; Conkey and Gero 1991; Conkey and Spector 1984; Engelstad 2001:345; Hjørungdal 1991, 1994). Figure 1 beautifully illustrates the traditional androcentric view of a Southern Scandinavian Bronze Age society. The men are present everywhere while the women are safely placed indoors; even in the darkness, taking care of children.

In this article I will start by giving a short account for how androcentrism may influence archaeology. By using two examples which I find representative for their time and tradition I will discuss whether androcentric archaeological research really informs us about men and what kind of knowledge it provides about prehistoric men and masculinity. I will argue that there is a need to explicitly study men and masculinities within archaeology and that it should be done within the already established feminist inspired gender archaeology.

First, however, I will shortly consider the relation between feminist archaeology and gender archaeology. Feminism as a political movement was crucial in the initial phase of gender studies in archaeology, as well as in science in general. While some today define their research as feminist archaeology (e.g. Conkey 2003; Engelstad 2004, 2007; Spector 1993; Voss 2000; Wylie 2007), most use the more neutral term gender archaeology. Many even avoid using the term "feminist" and several have explicitly 


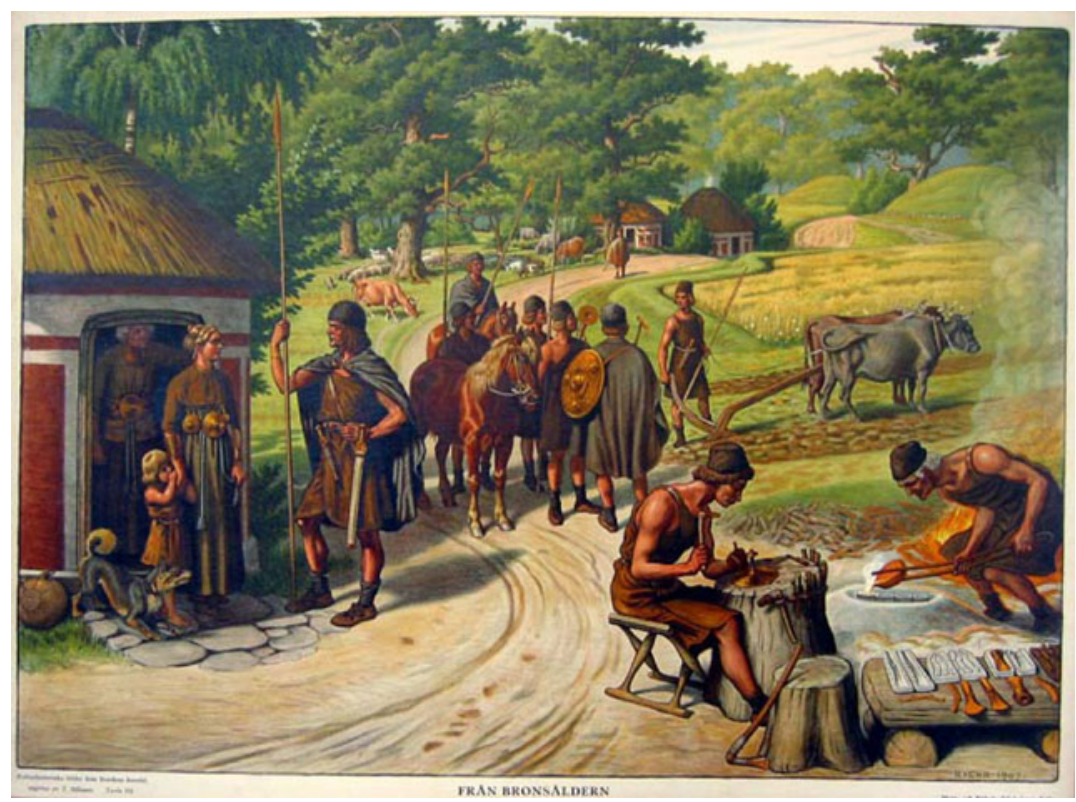

Figure 1. A Southern Scandinavian Bronze Age Society? (http://www-lu.hive.no/ plansjer/)

argued that gender archaeology should be separated from feminism (e.g. Gilchrist 1999; Moore 1997; Sørensen 2000). Ericka Engelstad (2007:226) suggests that the motivation is a desire for being "mainstream" and a fear of being controversial and political, and thus marginalized. She notes, however, that what is rejected seems to be a conception of feminism associated with 2nd wave feminism that existed in the 60s and 70s (see also Moi 2006). The major problem, however, is that many seem to confuse political feminism with feminist theory and consequently avoid employing feminist theory in archaeological gender studies.

I will not consider whether we ought to call it feminist or gender archaeology, but to concern with gender in archaeology without feminist theory, epistemology and critique of science is simply a process of add gender and stir, resulting in under-theorised studies which neither challenge the understanding of prehistory nor archaeological research practice (Engelstad 2004, 2007; Wylie 2007). It is beyond the scope of this paper to go into this any further, but I will return to the issue at the end of the paper and consider the relation between archaeological studies in masculinity and a gender archaeology based on feminist theory. In the following analyses and discussions the term feminist is used to describe works which are based on critical feminist theory and epistemology, while gender archaeology includes all archaeological studies focusing on gender, 
independent of theoretical framework or epistemology. Consequently, feminist archaeology is usually gender archaeology (though feminist theory may be applied to most problems), but gender archaeology is not necessarily feminist.

\section{Feminist Critic of Androcentrism}

From it's early beginning feminist critiques have discussed how androcentricm influences science in different ways (e.g. Gross 1977; Harding 1986; Slocum 1975). Also in archaeology several have discussed the impact of androcentrism on the study of prehistory (e.g. Conkey 1998[1984]:14-23; Engelstad 1991:510-512; Nelson 1997; Spencer-Wood 2006:61-65). For the purpose of this paper I will differentiate between the following three levels or types of androcentrism in archaeology, though they intermingle and might be said to cause each other. First, there is the overall focus on presumed male roles, like the (male) hunter, the (male) warrior, the (male) chief or the (male) farmer. Second, there is the major interest in processes or activities presumed to mainly concern men or where men are supposed to be the key actors; such as war, trade, sailing or religious rituals. The main criticism from feminist archaeologists towards these approaches in archaeology has not been the focus on men in itself, but the lack of attention to women, female roles, tasks and objects, and the underlying notion that everything in society always centres on men. In addition the critiques have revealed that when women are brought into the picture, female roles and tasks are often uncritically and stereotypically transferred from our modern society to the prehistoric community and considered lower in importance as well as status to those of men (see e.g. Bertelsen et al. 1987; Conkey 1998[1984]; Gilchrist 1999:17-22; Nelson and Rosen-Ayalon 2002:4; Wylie 1991, see also Spencer-Wood this issue).

The third level of androcentrism is more a matter of epistemology and concerns interpretations from a male standpoint. Feminist science critique has shown how social sciences, and as such archaeology, traditionally have understood society through the eyes of middle-age, middle-class, western white men (Haraway 1991; Harding 1986; Wylie 1991). This affects which questions they find interesting to investigate, as well as which explanations they find most plausible. The interpretations of different objects, buildings or structures often seem to start with the underlying question: How would a man use this? What makes this approach problematic is not primarily that archaeologists traditionally have been men or have seen the prehistory through their own eyes in itself. Rather it is the implicit assumption of objectivity and consequently the lack of critical reflection on which factors may influence their research and how. As men traditionally have not 
recognised themselves as gendered, gender is not seen as relevant for the studies and interpretations of prehistory as long as it is not explicitly concerning women (Kimmel 2000:6; Wylie 1991). A consequence is that (presumed) male activities and processes are recognized as representing society as a whole (Conkey 1998[1984]; Haraway 1991; Wylie 1991).

\section{Androcentric Archaeology}

Gender archaeology has so far mainly explored and discussed women in prehistory. This one-sided focus is justified by the more or less explicitly pronounced premise that while androcentric archaeology ignores women it deals with and informs us broadly about men. Still, beyond the questions of invisible women and the men representing them, this is rarely examined or discussed any further. A few have remarked that also male stereotypes may be transmitted to the past and thus shape the understanding of prehistoric men just as much as of women. However, this is not explored either or even considered as a problem (e.g. Conkey and Spector 1984; Gilchrist 1999). But can we expect that androcentric archaeology, which is not aware of the importance of gender in the first place, really provide knowledge about men and masculinity in prehistory? Stig Welinder (1997:63) even asks whether we, in spite of 200 years of androcentric archaeology, may now have more knowledge of prehistoric women than of prehistoric men as individual human beings.

To answer this we have to read androcentric archaeological literature with an explicit attention to how men and masculinities are presented (Caesar 1999b; Alberti 2006; Caesar 1999a; Welinder 1997). I have chosen two examples which I find representative for their present time and tradition, Brøndsted (1960) ${ }^{1}$ Danmarks Oldtid, Jernalderen (Prehistory of Denmark, Iron Age) and Anthony Harding's (2007) Warriors and Weapons in Bronze Age Europe. These works have been chosen because they are thorough material studies which also consider social aspects of society, but they represent completely different traditions of archaeology. They are also picked because I beforehand expected them to be androcentric. In the following I will explore and discuss how these works actually present men and masculinities and what kind of knowledge they provide about prehistoric men.

\section{Example 1: The Iron Age man}

The extensive traditional cultural historical study Danmarks Oldtid (Brøndsted 1960) is a respected and much cited work where the purpose is 
to describe the whens and wheres of Danish prehistory, from the Mesolithic until the end of the Viking age. Brøndsted presents immense amounts of excavated sites and illustrated objects and the overall focus is to identify culture-groups, their contacts and development. As such it is a typical example and representative of a large body of culture historical archaeological research (Trigger 1989).

When reading the part on the Early Iron Age, the most striking aspect of Brøndsteds (1960) interpretations of sites, objects, monuments, and rituals, is the absence of gender, men as well as women. He discusses the function and developments of objects, regional differences, religious beliefs, and social organisation but he never questions whether different artefacts, symbols or tasks were male or female. But by the use of male or female nouns (in Danish nouns might be gendered) together with pronouns like "he/she", "him/her" and "his/hers" when writing about different activities, he gives the impression that farming, fishing, making of pottery, metal-work, horse riding, house-building, road-construction, ditch-digging, or in the end, nearly all kinds of tasks were performed by men, with the exclusive exceptions of spinning, weaving and the wearing of jewellery. In addition words like "human", "people" or "Romans" are sometimes obviously used as synonymous with men. He also uses a lot more ink to account for objects like weapons, boats or even male clothing than to describe female clothing, jewellery, or tools for textile-working or food preparing. He even repeatedly comments upon the lack of specific types of weapons in different contexts and areas (e.g. 35, 147, 152, 160, 190, 222). Such patterns may of course be interesting and relevant but no other group of artefacts is considered to such an extent when they are not even present. This way Brøndsted clearly commits androcentrism at the previously mentioned first and second level.

One might say that if Brøndsted is right about textile-work being female, and that farming, pottery production or the building of boats were performed only by males, then his work contributes more to our knowledge about men than about women because it discusses these activities at a far greater length and with more details than explicitly presumed female activities. However, as he doesn't question, discuss, or put up a single argument, but simply assumes, we still don't know who did what. Brøndsted uncritically transfers modern gender stereotypes for example with regard to domestic and public spheres as he seems to take for granted that men were responsible for all outdoor activities. Another stereotype is the contrast between savage and aggressive men and peaceful women, for example in his interpretation and discussion of the Dejbjerg finding (Brøndsted 1960:73, 116).

The warrior is the only male role Brøndsted (1960) explicitly identifies, and I consider this the closest he gets to Early Iron Age men. Warfare and weapons were probably essential for the understanding of masculinity at times, but Brøndsted mainly focuses on the mere presence of weapons; the 
objects and their forms, chronology and proveniences. Even though he notices that contexts, amounts and assortments vary, he never questions the warrior's existence or even change of role or status in different periods or regions. The warrior is just the box into which weapons and related status objects are sorted. Thus the warrior becomes more a label or a tag than a role or a social category, because except for weapons it doesn't have any content. He turns out to be an ahistorical silhouette without any contact with his own community.

Brøndsted does not discuss what function or status a warrior had in society, whether all or just some men became warriors, what impact warfare and the presence of warriors had on society, if other roles were available to men by choice or birth, or in any other way explore it as a social phenomenon. He remarks that differences in the burials might reflect higher or lower status and he refers to different tasks, but then he lumps together the farmer, warrior and smith in one and the same person without any discussions. He doesn't distinguish between different groups of men except along ethnic lines, as he stresses a distinction between Roman, Celtic and Teutonic men.

Even though Brøndsted is mainly concerned with what he considers to have been male activities, they are, as feminist critique repeatedly has pointed out, generally presented as representing society as a whole, and thus also the third level of androcentrism is present in Brøndsted's study. Men are doing a lot of things, but they are usually not explicitly presented as men but, as already said, as "humans" or "people". However, by generalizing from the manly to the humanly, what is specifically masculine becomes invisible (Ekenstam 1998:19; Holter and Aarseth 1993:243-44; Kimmel 2000:5). As men seem to carry out almost everything, it is impossible to see what they were really doing. They are everywhere and as such not situated or located anywhere (see Haraway 1991).

It may seem out of place to show that Brøndsted doesn't take into account social theory that did not exist at the time his study was published. My intention is, however, not to criticise this study in particular or to analyse the androcentrism carried out by cultural historical archaeologists in general. I will, on the other hand, consider the actual presentation of men and masculinity in this kind of work and demonstrate that the assumption of feminist critique, that androcentric research informs us about men, is incorrect.

\section{Example 2: The Bronze Age Warrior}

A more recent example is Anthony Hardings (2007) Warriors and Weapons in Bronze Age Europe which is representative of a large and lately growing 
body of archaeological studies in warriors, warfare and violence as social phenomenons (e.g. Carman and Harding 1999; Molloy 2007; Nørgård Jørgensen and Clausen 1997; Osgood 2005; Osgood et al. 2000; Otto et al. 2006). With a long-term and geographically extensive approach Harding discusses Bronze Age warfare and its warriors from some point of emergence in the late Neolithic and until the beginning of the Early Iron Age. His purpose is to explore the form warfare took in different periods of time and what implications it had for the societies who practiced it (Harding 2007:31). The main focus is on the weapons; the swords, the daggers, the halberds, the axes, the spearheads, and the shields. Harding accounts for and discusses their extensiveness and development, but also evidence for their use like traumas on human remains or traces of defensive architecture.

Based on the discussions of the weapons Harding (2007) considers how raiding groups or small armies may have been organized according to size and armament and how societies were structured for the purpose of violence. He explores the specialization in armed violence and the emergence of a warrior identity, warrior elites, and the creation of warrior societies. In this evolutionary perspective the hunter gradually and progressively develops and is replaced by the warrior. Harding approaches warfare and warriors as social constructions and underlines that cultural factors that enable war are necessary in addition to a wish to go to war. In other words war cannot be understood by functionalistic explanations alone (2007:21).

Unlike Brøndsted (1960) Harding (2007) generally and explicitly talks about males and females. For example he states that stick-like human depictions on Iberian stelae and Scandinavian rock art are invariably male $(137,139)$ and argues that there are little or no evidence that females where involved in war bands (160). Accordingly, he consistently refers to the warrior as "him" with "his" differing weapons. Harding also employs the concept of gender when discussing burials but confuses it with sex and defines neither of them (see e.g. 55). Statements like " $\ldots$ artefacts that apparently indicate gender are not actually restricted to one gender or the other." (Harding 2007:141) reveals more on Harding's prejudice about gender than about the alleged gender indication. If an artefact is not restricted to one gender or the other, how can he know it is gender indicating?

Also this study has clear androcentric qualities. As the main issues are warriors and weapons, not the society in general, it is understandable and reasonable to a far greater extent than in Brøndsted (1960) that the focus is mainly on men. Harding can hardly be criticized for androcentrism just because he has written a book about male warriors. However, even though he is explicit about the warrior being male, he does not seem to realize that males usually constitute only half of the population, and consequently that 
most women and probably some or even many men were not warriors. Sometimes it becomes rather obvious that he sees men as representative of the society as a whole, for example when he asks "How did the users of Beaker pottery use their weapons?" (Harding 2007:53). As Harding argues that neither women nor children were actually warriors (2007:59) and (with an exception at 149) repeatedly asserts that warriors were male, he apparently has only men in mind when talking about "the users of Beaker pottery". Unless he thinks that only men were allowed to use pottery in Beaker cultures he hereby excludes women and children as members of the Beaker society.

Harding (2007:57) states that people buried with weapons reflect groups of people that might have taken part in fighting. However, when daggers are found in burials with females or children he argues that their presence does not necessarily mean that the deceased were warriors, as the daggers were probably too small to be effective in hand-to-hand fighting anyway. In other words, a dagger in a male burial is discussed as a weapon meant for fighting and war (see e.g. 35, 57, 169), while a dagger in the burial of a female or a child transforms to a non-efficient knife (Harding 2007:59). Further, Harding (2007:141) expresses surprise that toilet equipment like razors and tweezers are commonly found in burials otherwise obviously male. He even points to toilet equipment as an example of the above mentioned gender indicating artefacts that are not restricted to the gender they should indicate. It may seem like Harding thinks toilet implements inherently signify females. The fact is that in Late Bronze Age razors and tweezers are almost exclusively found in male burials and as such they probably are gender indicating; they indicate male burials (Kristiansen 1998:181; Skogstrand in prep; Thrane 1984:129). Harding (2007:141) proclaims that to be a warrior was not just a matter of appearing big and strong, but also a question of appearing well-tended and suggests that there may have been an effeminate or homoerotic element in this beautification.

These examples illustrate that Harding (2007) has clear expectations to the Bronze Age warrior. First of all he takes for granted a constant presence of the warrior from the moment he replaces the Neolithic hunter. The existence of the warrior (or hunter) is a premise for the interpretations of weapons in male burials, not a conclusion of the discussion of artefacts. Further, the daggers in female and child burials and the razors and tweezers in male burials could potentially challenge the stereotype images of prehistoric women as well as that of strong and unkempt male warriors. However, when the archaeological record doesn't meet Harding's prejudices it is explained away so that the expectations may be fulfilled and the stereotype for the most part sustained. Instead of altering the understanding of what was considered masculine, the beautification is presented as something feminine or perhaps even homoerotic but this is not elaborated 
any further in relation to the warrior role. The interpretation of homoerotic elements may indeed be right (see e.g. Joyce 2000; Skogstrand 2008; Yates 1993), but cannot be based solely on evidence that Bronze Age warriors cared for their bodily appearance.

\section{What Does Androcentric Archaeology Tell Us About Men?}

Both Brøndsted (1960) and Harding (2007) commit androcentrism of all the previously mentioned kinds. None of these studies inform us much about prehistoric women, but I will assert that they do not really tell us much about men either. They are mainly concerned with presumed male roles and male activities, but while Brøndsted generally presents them as people and humans, making the explicit manly and masculine disappear into the shadows, Harding clearly states that the warrior was male and transfers readymade modern stereotypic ideas on male roles. Since masculinity is not questioned, the image of men in both studies becomes a never ending reproduction of male archetypes like the warrior, the farmer, the hunter and the chief or in other words; the breadwinner and the man in charge fulfilling 19th century masculine ideals of being head of house, making decisions, being stout and taking risks (Caesar 1999b; Hjørungdal 1994; Welinder 1997). The prehistoric man lives up to mythic ideas of an original, inborn and natural masculinity, which is rough and fierce and explicitly put in contrast to the peaceful feminine (Brøndsted 1960:73). Consequently, the impression of the male becomes one-dimensional and shallow and he doesn't change even though the archaeological record and thus society and cultural norms obviously did.

In studies like Brøndsted's (1960) men become actions, large scale social and technological developments, or cultural groups, and as such they seem unaffected by gender. For example, Brøndsted (1960:154, 157) states that smith tools are found in male burials, and that iron production and smith work must have been the most important among the crafts (250). Nevertheless, neither in his thorough discussion of iron production technology (see 110-113) nor anywhere else is the possible relation between iron technology and men discussed any further. Thus, how the introduction and incorporation of iron technology may have influenced gendered structures remains unknown. Most likely, the introduction of iron production had consequences for the division of labour or task differentiation (see e.g. Räf 2006; Spector 1983, 1993) as it is a rather time consuming activity. If groups, possibly consisting mainly of men, went away for weeks to produce iron, this must have affected the accomplishment and division of other tasks in the community. Further, iron production requires the knowhow as well as access to and control over human and raw material resources 
(Larsen 2009; Østigård 2007). As the economical importance of iron production increased rapidly in Southern Scandinavia by the end of the PreRoman Iron Age, tasks related to different stages in the production, in all probability, created specific gendered contexts of action and consequently contexts of power (Conkey 1991). In addition, a possible repeated association between men and iron production may have created new notions of masculinity, and metaphors related to iron production might have been used for expressing, legitimating and explaining masculinity (see Butler 2006[1990]:190-193). In other words, Brøndsted's study tells a lot about iron technology, but little of how it may have affected the lives of men.

Harding (2007) gives a nuanced presentation of possible developments of the hunter/warrior from the Neolithic to the Bronze Age, mainly concerning the weaponry and ways of warfare. He stresses that war was pervasive in the development of Bronze Age society and lists the increasing need for craftsmen, traders, travellers and military training of young men as examples of changes in society (Harding 2007:181). In spite of the fact that he characterizes warfare as a single-sexed arena Harding never considers whether the emergence and development of the warrior role may have been related to changes in gender structures and hereunder notions of masculinity. On the contrary, he struggles hard to unpack what happens as the warrior role develops throughout the Bronze Age. He aims to discuss how warrior identity transformed over time and how it was related to changes in society but it remains unclear what he means by identity as well as warrior ideology and how it influenced other social structures. He stresses bellicosity as an important premise for war (2007:24), but seems unaware that universally and throughout history a variety of cultures and belief systems have developed concepts of masculinity that motivate and induce men to fight (Goldstein 2004:264). A large body of literature and research shows that war systems; the ways that societies organize themselves to participate in potential or actual wars, and the cultural understanding of masculinity are closely interrelated (e.g. Braudy 2005; Dudink et al. 2004; Goldstein 2004; Spierenburg 1998). "Gender roles adapt individuals for war roles, and war provides the context within which individuals are socialized into gender roles." (Goldstein 2004:6). Hardings study contains potentially a lot of information about men and masculinities but the male warrior remains a category which explains the presence of weapons. In contradiction to Brøndsted, Harding could indeed be criticised for not taking gender into account. That is, however, not the point of this discussion.

What is missing from the non-gendered archaeology of men is the idea of masculinity (Connell 2005[1995]:28). Gendered mechanisms, how gender may structure action, space or development or how masculinity may differentiate between different groups of men (see e.g. Connell 1995) are not a part of the understanding of prehistoric men. The fact that men are 
representing the entire prehistoric society is not simply because women are ignored; it is mainly because men are not gendered.

To ignore masculinity is to leave the idea of this undifferentiated, universal "man" in place and neglect his complexity (Caesar 1999b:115). As androcentric studies apply "man" and "masculinity" as universal norms they blur the image of prehistoric men and it becomes even more difficult to explore masculinity. In some respects there is an unfinished task in finding and making prehistoric men visible as a heterogeneous group as well as individuals. The man as the norm may be challenged by giving attention to women but the stereotype image of prehistoric men is not altered. To explore prehistoric men and masculinity might on the other hand confront androcentric archaeological studies just as much as to study women in prehistory. By gendering prehistoric men it becomes clear that they can only stand for themselves, rather than represent the whole of humanity (Alberti 2006:404; see also Knapp 1998c).

\section{Gendering Prehistoric Men}

The main reason to study masculinity in archaeology is because it provides interesting and relevant knowledge about prehistoric societies and how they may have been structured by gender. While some have argued strongly for the inclusion of men and masculinity into the archaeology of gender (e.g. Alberti 2006; Caesar 1999a, b; Knapp 1998a, c; Meskell 1999:61-64) others have expressed reluctance to study men because they fear it may be a backlash to the studies of women and reinstate "man" as the universal historical subject (see Alberti 2006:403; Knapp 1998b:118; Knapp 1998c:92; White 2000). I will assert that we do not have a gendered archaeology as long as men are left out as we cannot explore gender systems by focusing on women alone. On the contrary, "If we problematize women and leave men as an untheorized group, the male position is indirectly privileged and gender studies are regarded as the domain of women." (Meskell 1999:84). Without critical studies in prehistoric men and masculinities, men will remain an undifferentiated dominant group (Alberti 2006:411). To study men in archaeology is not just a question of "adding men and stir". To focus explicitly on men is in itself no guarantee for a gendered study as the preceding discussion of Harding's (2007) work illustrates. "To "do" men is not to comprehend masculinity [...]" (Knapp 1998b:117). To avoid androcentrism, and to obtain knowledge of the gendered men in prehistory we need to critically explore how masculinities may have structured society, affected power and individual actions and identities, and even question the concept of masculinity itself and challenge any a priori binary understandings of gender (see Alberti 2006). 
Modern critical men's studies are for the most deeply rooted in feminist theory (Connell 2005[1995]; Ekenstam 2006; Kimmel 2000; Knapp 1998c; Lorentzen and Mühleisen 2006; Petersen 2003; Whitehead 2002). There is thus no contradiction between a gender archaeology based on feminist theory and studies in prehistoric men and masculinities. Benjamin Alberti (2006:402-403) argues that there is no need for a separate archaeology of masculinity, as the necessary theoretical and conceptual frameworks are already in place within the feminist inspired gender archaeology, something which is generally supported by the few publications explicitly discussing men and masculinity in prehistory (see e.g. Alberti 1997, 2006; Caesar 1999a; Foxhall 1998; Joyce 2000, 2007; Knapp 1998c; Lislerud 2001; Skogstrand 2006; Voss 2008). In fact, without feminist theory and epistemology and awareness that masculinity is neither monolithic nor static, but divergent and multiple configurations of discursive practice (Connell 1995; Connell and Messerschmidt 2005; Demetriou 2001), a focus on men and masculinity within archaeology risks ending up in traditional androcentrism.

\section{Acknowledgment}

Thanks to Ericka Engelstad for insightful discussions and helpful comments on previous drafts of this paper.

\section{Open Access}

This article is distributed under the terms of the Creative Commons Attribution Noncommercial License which permits any noncommercial use, distribution, and reproduction in any medium, provided the original author(s) and source are credited.

\section{Note}

1. The first edition was published in 1940, but this study is based on the second edition.

\section{References Cited}

Alberti, B.

1997. Archaeology and Masculinity in Bronze Age Knossos, Department of Archaeology. University of Southampton, Southampton. 
2006. Archaeology, Men, and Masculinities. In Handbook of Gender in Archaeology, edited by S. M. Nelson. AltaMira Press, Lanham, Md.

Bertelsen, R., A. Lillehammer, and J.-R. Næss

1987. Were They All Men?: An Examination of Sex Roles in Prehistoric Society: Acts from a Workshop Held at Utstein kloster, Rogaland, 2-4 November 1979 (NAM-forskningsseminar $n r$ 1). Arkeologisk museum i Stavanger, Stavanger.

Braudy, L.

2005. From Chivalry to Terrorism: War and the Changing Nature of Masculinity. Vintage Books, New York.

Brøndsted, J.

1960. 3. Jernalderen Danmarks oldtid. Gyldendal, København.

Butler, J.

2006[1990]. Gender Trouble. Feminism and the Subversion of Identity. 2nd ed. Routledge, New York.

Caesar, C.

1999a. The Construction of Masculinity-The Driving Force of History: A New Way of Understanding Change in the Past. Lund Archaeological Review 5:117-136.

1999b. Urmannen - den osynliga normen. Maskulinitetsforskning inom arkeologin. In Han, hon den, det. Att integrera genus och kön $i$ arkeologi, edited by C. Caesar, I. Gustin, E. Iregren, B. Petersson, E. Rudebeck, E. Räf and L. Ströbeck. Report Series No.65, University of Lund.

Carman, J., and A. Harding

1999. Ancient Warfare: Archaeological Perspectives. Stroud, Sutton.

Conkey, M. W.

1991. Contexts of Action, Contexts of Power: Material Culture and Gender in the Magdalenian. In Engendering Archaeology. Women and Prehistory, edited by J. M. Gero and M. W. Conkey. Blackwell, Oxford.

2003. Has Feminism Changed Archaeology?. Signs 28(3):867-880.

Conkey, M. W., and J. M. Gero

1991. Tensions, Pluralities, and Engendering Archaeology: An Introduction to Women and Prehistory. In Engendering Archaeology. Women and Prehistory, edited by J. M. Gero and M. W. Conkey. Blackwell, Oxford.

Conkey, M. W., and J. D. Spector

1984. Archaeology and the Study of Gender. In Advances in Archaeological Method and Theory, edited by M. B. Schiffer. Academiv Press, New York. 
1998[1984]. Archaeology and the Study of Gender. In Reader in Gender Archaeology, edited by K. Hays-Gilpin and D. S. Whitley. Routledge, London.

Connell, R. W.

1995. Masculinities. Polity Press, Cambridge.

2005[1995]. Masculinities. 2nd ed. Polity Press, Cambridge.

Connell, R. W., and J. W. Messerschmidt

2005. Hegemonic Masculinity. Rethinking the Concept. Gender and Society 19(6):829-859.

Demetriou, D. Z.

2001. Connell's Concept of Hegemonic Masculinity: A Critique. Theory and Society 30:337-361.

Dudink, S., K. Hagemann, and J. Tosh (editors)

2004. Masculinities in Politics and War: Gendering Modern History. Manchester University Press, Manchester.

Ekenstam, C.

1998. Historisk mannsforskning. In Rädd at falla. Studier $i$ manlighet, edited by C. Ekenstam, T. Johanson, J. Kousmanen, and A. Nilsson. Gidlunds fõrlag, Hedemora.

2006. Män, manlighet och omanlighet i historien. In Män i Norden. Manlighet och modernitet 1840-1940, edited by J. Lorentzen, and C. Ekenstam. Gidlund, Hedemora.

Engelstad, E.

1991. Images of Power and Contradiction: Feminist Theory and Post Processual Archaeology. Antiquity 65(248):502-514.

2001. Desire and body maps: all the women are pregnant, all the men are virile, but.... In Theoretical perspectives in Rock Art Research, edited by K. Helskog. Institutt for sammenliknende kulturforskning, Novus forlag, Oslo.

2004. Another F-word? Feminist Gender Archaeology. In Combining the Past and the Present. Archaeological Perspectives on Society, edited by T. Oestigaard, N. Anfinset, and T. Saetersdal. BAR International Series, Oxford.

2007. Much More Than Gender. Journal of Archaeological Method and Theory 14:217-234.

Foxhall, L.

1998. Introduction. In When Men Were Men: Masculinity, Power and Identity in Classical Antiquity, edited by L. Foxhall, and J. Salmon. Routledge, London.

Gilchrist, R.

1999. Gender and Archaeology. Contesting the Past. Routledge, London. 
Goldstein, J. S.

2004. War and Gender: How Gender Shapes the War System and Vice Versa. Cambridge Univ. Press, Cambridge.

Gross, R. M.

1977. Androcentrism and Androgony in the Methodology of History of Religions. In Beyond Androcentrism: New Essays on Women and Religion, edited by R. M. Gross. Scholars Press, Missoula, Mont..

Haraway, D. J.

1991. Situated Knowledge: The Science Question in Feminism and the Privilege of Partial Perspective. In Simians, Cyborgs, and Women. The Reinvention of Natures. Free Association Books, London.

Harding, A.

2007. Warriors and Weapons in Bronze Age Europe. In Archaeolingua Series Minor, edited by E. Jerem, and W. Meid. Archaeolingua, Budapest.

1986. The Science Question in Feminism. Cornell University Press, Ithaca, N.Y..

Hjørungdal, T.

1991. Det skjulte kjønn: patriarkal tradisjon og feministisk visjon i arkeologien belyst med fokus på en jernalderkontekst. Almqvist \& Wiksell International, Lund.

1994. Poles Apart. Have There Been Any Male and Female Graves?. Current Sweedish Archaeology 2:141-150.

Holter, Ø. G., and H. Aarseth

1993. Menns livssammenheng. Ad Notam Gyldendal, Oslo.

Joyce, R. A.

2000. A Precolombian Gaze: Male Sexuality Among the Ancient Maya. In Archaeologies of Sexuality, edited by B. L. Voss, and R. A. Schmidt. Routledge, London.

2007. Embodied Subjectivity: Gender, Femininity, Masculinity, Sexuality. In A Companion to Social Archaeology, edited by L. Meskell, and R. W. Preucel. Blackwell, Malden, Mass..

Kimmel, M. S.

2000. The Gendered Society. Oxford University Press, New York.

Knapp, A. B.

1998. Boys will be Boys: Masculinist Approaches to a Gendered Archaeology. In Reader in Gender Archaeology, edited by K. Hays-Gilpin, and D. S. Whitley. Routledge, London and New York.

1998b. Masculinist Archaeology? Respons to the Respondents of Who's Come a Long Way, Baby? 1998. Archaeological Dialogues 2:115-118.

1998c. Who's Come a Long Way, Baby? Masculinist Approaches to a Gendered Archaeology 1998. Archaeological Dialogues 2:91-104. 
Kristiansen, $\mathrm{K}$.

1998. Europe Before History. Cambridge University Press, Cambridge.

Larsen, J. H.

2009. Jernvinneundersøkelser, Varia. Fornminneseksjonen, Oslo.

Lislerud, A.

2001. Membrum virile: falliske menneskefigurer i sør-skandinaviske helleristninger: en feministisk tilnorming til bronsealderens maskulinitet, A. Lislerud, Tromsø.

Lorentzen, J., and W. Mühleisen (editors)

2006. Kjønnsforskning: en grunnbok. Universitetsforl, Oslo.

Meskell, L.

1999. Archaeologies of Social Life, Age, sex, Class et cetera in ancient Egypt. Blackwell, Oxford.

Moi, T.

2006. I Am Not a Feminist, But...: How Feminism Became the F-Word. PMLA (Transactions and Proceedings of the Modern Language Association of America) 121(5):1735-1741.

Molloy, B. (editor)

2007. The Cutting Edge. Studies in Ancient and Medieval Combat. Tempus Publishing Limited, Stroud.

Moore, J.

1997. Conclusion: The Visibility of the Invisible. In Invisible People and Processes: Writing Gender and Children into European Archaeology, edited by J. Moore, and E. Scott. Leicester University Press, London.

Nelson, S. M.

1997. Gender in Archaeology: Analyzing Power and Prestige. AltaMira Press, Walnut Creek, Calif..

Nelson, S. M., and M. Rosen-Ayalon

2002. Introduction. In In Pursuit of Gender: Worldwide Archaeological Approaches, edited by S. M. Nelson, and M. Rosen-Ayalon. AltaMira Press, Walnut Creek, Calif..

Nørgård Jørgensen, A., and B. L. Clausen (editors)

1997. Military aspects of Scandinavian society in a European perspective, AD 11300: Papers from an International Research Seminar at the Danish National Museum, Copenhagen, 2-4 May 1996, edited by A. Nørgård Jørgensen and B. L. Clausen, vol. 2. The National Museum, Copenhagen.

Osgood, R.

2005. The Unknown Warrior: The Archaeology of the Common Soldier. Sutton, StTroud. 
Osgood, R., S. Monks, and J. Toms

2000. Bronze Age Warfare. Sutton, Stroud.

Otto, T., H. Thrane, and H. Vandkilde (editors)

2006. Warfare and Society: Archaeological and Social Anthropological Perspectives. Aarhus University Press, Aarhus.

Østigård, T.

2007. Transformatøren: ildens mester $i$ jernaldern, Rituelle spesialiteter $i$ bronse- og jernalderen. Göteborg universitet, Institutionen för arkeologi och antikens kultur, Göteborg.

Petersen, A.

2003. Research on Men and Masculinities: Some Implications of Recent Theory for Future Work. Men and Masculinities 6(1):64-69.

Räf, E.

2006. Bara skinn och ben?-att söka efter hantverksspår. In Det Arkeologiske kjønn. Foredrag fra et seminar om kjønn og arkeologi, Vitlycke Museum 30. januar - 1. februar 2003, edited by L. Skogstrand, and I. Fuglestvedt. Unipub, Oslo.

Skogstrand, L.

2006. I krig og evighet? Kjønnsideologiske forestillinger i yngre bronsealder og eldre førromersk jernalder belyst gjennom graver og helleristninger i Østfold. In Kjønnsideologi og kosmografi i den østnorske bronsealder, edited by C. Prescott. Oslo arkeologiske serie, Oslo.

2008. Hieros-Gamos, a Matter of Gender Disorder?. In Oslo Archaeological SeriesFacets of Archaeology. Essays in Honour of Lotte Hedeager on her 60th Birthday, edited by K. Chilidis, J. Lund, and C. Prescott. OAS, Oslo Archaeological Series. Unipub, Oslo: OAS.

in prep. Warriors and other Men. Notions of Masculinity from the Bronze Age to the Iron Age expressed through burials, 1100 BC-400 AD: Ph.D. thesis in preparation. Museum of Cultural History, University of Oslo.

Slocum, S.

1975. Woman the Gatherer: Male Bias in Anthropology. In Toward an Anthropology of Women, edited by R. R. Reiter. Monthly Review Press, New York.

Spector, J. D.

1983. Male/Female Task Differentiation Among the Hidatsa: Toward the Development of an Archaeological Approach to the Study of Gender. In The Hidden Half: Studies of Plains Indian Women, edited by P. Albers, and B. Medicine. University Press of America, Washington.

1993. What This Awl Means: Feminist Archaeology at a Wahpeton Dakota Village. Minnesota Historical Society Press, St. Paul, Minn.. 
Spencer-Wood, S.

2006. Feminist Theory and Gender Research in Historical Archaeology. In Handbook of Gender in Archaeology, edited by S. M. Nelson. AltaMira Press, Lanham, Md..

Spierenburg, P.

1998. Masculinity, Violence, and Honor: An Introduction. In Men and Violence. Gender, Honor, and Rituals in Modern Europe and America, edited by P. Spierenburg. Ohio State University Press, Colombus.

Sørensen, M. L. S.

2000. Gender Archaeology. Polity Press, Cambridge.

Thrane, $\mathrm{H}$.

1984. Lusehøj ved Voldtofte: en sydvestfynsk storhøj fra yngre broncealder. Odense.

Trigger, B. G.

1989. A history of Archaeological Thought. Cambridge University Press, Cambridge.

Voss, B. L.

2000. Feminisms, Queer Theories and the Archaeological Study of Past Sexualities. World Archaeology 32(2):180-192.

2008. The Archaeology of Ethnogenesis: Race and Sexuality in Colonial San Francisco. University of California Press, Berkeley, Calif..

Welinder, $\mathrm{S}$.

1997. Att väksa upp til man på stenåldern. In Gender och arkeologi, edited by B. Johnsen, and S. Welinder. Mitthögskolan, Östersund.

White, S.

2000. Did the Earth Move? The Hazards of Bringing Men and Masculinities into Gender and Development. IDA Bulletine 31:33-41.

Whitehead, S. M.

2002. Men and Masculinities: Key Themes and New Directions. Polity Press, Cambridge.

Wylie, A.

1991. Gender Theory and the Archaeological Record: Why Is There No Archaeology of Gender?. In Engendering Archaeology: Women and Prehistory, edited by J. M. Gero, and M. W. Conkey. Blackwell, Oxford.

2007. Doing Archaeology as a Feminist. Journal of Archaeological Method and Theory 14:209-216.

Yates, T.

1993. Frameworks for an Archaeology of the Body. In Interpretative Archaeology, edited by C. Tilley. Berg Publishers, Oxford. 